\title{
ESSENTIALITY OF STAKEHOLDER MANAGEMENT FOR UNIVERSITY SURVIVAL
}

\author{
M. Khanyile \\ Registrar Office: Deputy Director \\ University of South Africa \\ Pretoria, South Africa \\ e-mail: khanym@unisa.ac.za
}

\section{ABSTRACT}

Universities are struggling to identify and analyse who their stakeholders are, what stake(s) they claim; what threats or opportunities stakeholders present; what responsibility they have towards stakeholders; and to conflate the terms "publics" and "stakeholders". Management of stakeholders entails a symbiotic and epistemological relationship between system-in-focus, stakeholders and the environment. The reductionist approach cannot assist in gaining an understanding of what stakes stakeholders claim. The identification of stakeholders, as well as their needs, must be done by a university before the priorities and relational strategies are determined for each stakeholder. As a complex adaptive system operating in complex, ever-changing, diverse and shifting environments, a university needs strong stakeholder management strategies to adapt to its own changing needs and expectations, as well as those of its stakeholders. Stakeholder salience and identification could enable universities to understand the typology of stakeholder attributes, as well as assist in defining taxonomies relevant to each scenario. In order to enable universities to respond to stakeholders' competing needs, "strong management" is required, and should include a paradigm shift to the concept of "economic rationalism" in educational service delivery. This article seeks to highlight the vital role played by stakeholder management in the long-term survival of universities.

Keywords: complex adaptive system, publics, stakeholder, stakeholder management, stakeholder theory, university

\section{INTRODUCTION}

Universities are struggling to identify and analyse who their stakeholders are, what stake(s) they claim; what threats or opportunities stakeholders present; what responsibility the university has towards its stakeholders; and what the difference between the term "publics" and "stakeholders" is. The term stakeholder refers to any individuals or groups who have an interest in what the system is doing (Jackson 2003). Stakeholders have a direct or indirect interest in the way that the business operates (Louw and Venter 2008). They can be defined as individuals or groups, both internal and external, which influence a business or have a stake in it (Pearce and Robinson 2007). According to Louw and Venter (2008), it is essential for every 
organisation to identify its key stakeholders and to clearly define its key responsibilities towards them. The key stakeholders are influential and play a critical role in the success (or lack thereof) of an organisation. They can be defined as those who have the power to thwart the organisation's achievement of its objectives, as well as the potential to cause the organisational goals to fail (Prokopy et al. 2015).

Prior to the determination of priorities and relational strategies for each stakeholder, a university must first identify these stakeholders, as well as their needs. However, these stakeholders are virtually limitless in number (Doh and Quigley 2014). According to Bobeica (2011), identifying stakeholders is a difficult task, because nobody knows exactly who they are. Stakeholder management seeks to develop a framework that responds to managers' concerns, as managers face consistently high levels of turbulence and change in their environment (Freeman and McVea 2001). One of the key determinants of an organisation's ability to manage change effectively is organisational structure (Vagnoni and Cavicchi 2015). This shift heralds a new era and a new school of thought.

As many theorists began to realise that a business does not operate in isolation (Hakansson and Ford 2002), the concept of wealth maximisation was introduced, in order to focus on maximising the benefit for all business stakeholders (Agle 2008). According to Ehlers and Lazenby (2007), wealth maximisation includes all spheres of the business, in order to emphasise sustainability and long-term survival. Sixty-four percent of 100 companies from the Fortune 500 list supported management approaches that aim to "maximize the wellbeing of all stakeholders” (Agle 2008, 154). The goal of survival is taken for granted, and an organisation that is unable to survive is incapable of satisfying the interests of any of its stakeholders (Pearce and Robinson 2007). Wealth maximisation sought to address the importance of all stakeholders for the future sustainability of the business. The purpose of every organisation is, to varying degrees, to serve the interests of its stakeholders (Louw and Venter 2008).

Leaders face high levels of complexity, change, and diversity in the turbulent environment that exists today (Jackson 2003). According to Sturmberg, Martin and Katerndahl (2014), complex adaptive systems are collections of many different components, known as agents, which interact in a non-linear fashion without external supervisory influence. The presumption of theories linked to complex adaptive systems is that a system's adaptation to its environment is made possible through the adaptive efforts of individual agents, who want to increase their own profits (Anderson 1999). Stakeholder management facilitates the development of a comprehensive framework for understanding the complex interactions between organisations and their environments, both internal and external (Doh and Quigley 2014). In recent years, increasing attention has been paid to the concept of stakeholders (Cheng, Millar and Ju Choi 2006). 


\section{DEFINITIONS OF A STAKEHOLDER}

According to Freeman (in Jongbloed, Enders and Salerno 2008, 305), the origins of the stakeholder concept can be found in the field of business science. Freeman (in Berman et al. 1999, 491) and Pesqueux and Damak-Ayadi $(2005,4)$ define a stakeholder as "any group or individual that can affect or be affected by the realisation of a company's objectives”. Clarkson $(1995,106)$ indicates that "stakeholders are persons or groups that have, or claim, ownership, rights, or interests in a corporation and its activities, past, present, or future”. However, there does not appear to be a universally recognised definition of a stakeholder (Polonsky 1995; Polonsky, Carlson and Fry 2003). In business organisations, a stake refers to "legal, moral, or presumed” claims of having the power to influence the organisation's "behaviour, direction, process, or outcomes” (Mitchell, Agle and Wood 1997, 859).

The Stanford Research Institute coined the term "stakeholder” in 1963, which was defined as "those groups without whose support the organisation would cease to exist” (Zsolnai 2006, 38). However, it was meant to expand the notion that management only had to be sensitive towards stockholders (Jongbloed et al. 2008, 305; Mainardes, Alves and Raposo 2012). The term "stakeholder” brings new meaning to the university's conduct, role and responsibility, and changes the university's interaction with society (Jongbloed et al. 2008). The stakeholder concept is a fairly new way of describing how a business functions, and for enabling the business to define its main purposes. The description of a stakeholder may be guided by users' conceptions (Tetřevová and Sabolová 2010). The stakeholders with whom a university is expected to interact comprise organisations and groups of individuals (Jongbloed et al. 2008). Mainardes et al. (2010) indicate that stakeholders in public and non-profit organisations are individuals or groups that can directly influence the sustainability of the organisation. Furthermore, Berman et al. (1999) suggest that stakeholders are able to impact the success of the organisation.

The student community is the most important community for a university (Jongbloed et al. 2008), and when students complete their studies, they become clients of the university (Mok 1999) or customers (Jongbloed et al. 2008), which means that their admission now involves access instead of selection (Mok 1999). According to Preston (in Clarkson 1995, 106), there are "four parties to any business in the order of their importance", namely "customers, employees, community, and stockholders”. Jongbloed et al. (2008) argue that traditional university stakeholders, such as students and the government, are now being replaced by, among others, industry. Therefore, the universities of today have many stakeholders and potential partners (Jongbloed et al. 2008).

In recent times, there has been a convolution and conflation of the terms "publics" and 
“stakeholders". This nomenclature has been used interchangeably. Publics are "groups of individuals who develop their own identities, and perhaps representations of their collective interests, in relation to the system” (Johansson 2009, 53). As issue-based organisations fight for their survival, the notion of life-world organisations "independent of the system" becomes nonsensical.

The conceptualisation of the term "publics" in the field of public relations remains extremely simplistic, and reflects the prevailing managerial and normative traditions in this field. The definition of publics and the study of their dynamics straddle fields such as sociology, media studies, and marketing. Through a more critical and reflective approach, this article attempts to explore areas of research which support public relations theory and practice in coping with a complex and uncertain environment.

Publics form established responses to specific issues in the form of issue-based organisations. As Jones $(2002,49)$ points out, "the social reality of the organisation is created and maintained for internal and external stakeholders through language and symbolic action”. These two terms, namely "stakeholders" and "publics", should not be conflated because they create convolution.

\section{STAKEHOLDER THEORY}

Stakeholder theory has become the focus of numerous debates in different disciplines, which has ultimately led to its emergence as a dominant discourse (Mitchell et al. 2007; Pesqueux and Damak-Ayadi 2005). The foundation of an organisation's relational model, in terms of stakeholder theory, is organisational group relationships (Carroll and Buchholtz 2014; Felix and Ogbor 2014; Pesqueux and Damak-Ayadi 2005). In the higher education environment, stakeholder theory can be useful in explaining the focus on various communities and the relationship between a university and its communities (Jongbloed et al. 2008). According to Green (2014), a university and society need to be connected in such a way that the needs of society are at the core of universities' activities. Although stakeholder management is an important element of the organisational strategy, it does not drive such strategy (Berman et al. 1999).

Stakeholder theory is managerial (Freeman, Wicks and Parmar 2004) and can be articulated by asking the following two questions: (a) for what purpose does the organisation exist? and (b) what is management's responsibility towards its stakeholders? (Freeman 1994). According to Jackson (2003), stakeholders need to be educated about organisational visions and changes, as well as being made aware of the implications of the system of values and beliefs that they have. Stakeholder management has fundamental implications for the university's survival (Jongbloed et al. 2008), as it assists organisations to recognise and analyse the 
characteristics of individual and group stakeholders that either influence or are influenced by the organisation's activities and decisions (Mainardes et al. 2012). Universities are encouraged to have a symmetrical dialogue with their stakeholders within communities (Jongbloed et al. 2008). According to Zsolnai (2006), all stakeholders are morally considerable. For those attempting to establish symmetrical dialogue with such organisations, they must be aware of the way in which the organisation's reality is constituted through language, and then act accordingly (Jones 2002).

The multitude of stakeholders with whom a university has to engage implies the need for an effective strategy, in order to understand and manage relationships with stakeholders, which has a definite impact on the university's success (Jongbloed et al. 2008). Vankataraman (in Freeman et al. 2004) posits that a stakeholder approach will facilitate the development of a robust entrepreneurship theory, where entrepreneurial risk and its role are clearly understood. Stakeholder theory assumes that values are part of a business, and rejects the theory of separation (Freeman 1994). According to Freeman et al. (2004, 364), the separation thesis assumes, from the beginning, that ethics and economics can be "neatly and sharply separated".

Freeman and Gilbert (in Berman et al. 1999, 493) state that "we cannot connect ethics and strategy, unless there is some point of intersection between the values and ethics we hold and the business practices that exemplify these values and ethics”. This categorisation separates ethical issues from mainstream business theories, hence separating the stakeholder approach from a mainstream business strategy (Freeman and McVea 2001). Stakeholder management refers to the effective management of relationships with stakeholders (Felix and Ogbor 2014). In the field of business ethics, it has become one of the key developments (Wicks, Gilbert and Freeman 1994).

\section{STAKEHOLDER IDENTIFICATION AND SALIENCE}

The identification and prioritisation of stakeholders are essential elements of stakeholder analysis, particularly if a university wishes to gain a significant competitive advantage in today's turbulent tertiary education environment, which is characterised by fierce and rising competition (Clarkson 1994; Slabá 2015). This is a critical challenge in stakeholder management (Mitchell et al. 1997; Parent and Deephouse 2007). Stakeholder analysis can assist the university to determine its stakeholders, and their salience (Jongbloed et al. 2008). However, the literature reveals that many organisations do not conduct a formal analysis of stakeholders' interests, since they foresee difficulties in mapping these interests (Payne, Ballantyne and Christopher 2005). According to Mainardes et al. (2010), the identification of university stakeholders has not been empirically researched, which means that the process of identifying university stakeholders needs to be developed from scratch. 
Jongbloed et al. (2008) argue that stakeholder identification within the university does not occur at the institutional level, but at different levels, because of professional domination, fragmented decision making, and the diffusion and devolution of power. According to Burrows (1999), mechanisms to determine the similarities and differences between stakeholder groups are needed. Traditional methods for identifying stakeholders have not been applied in the context of universities (Mainardes et al. 2010). In this context, identifying stakeholder groups is not a simple process (Jongbloed et al. 2008). It is important that participants are identified and classified in accordance with their relative importance, and that relationships are established with them in terms of their salience (Mainardes et al. 2012). Universities need to recognise each stakeholder's expectations and needs or demands, which goes beyond merely identifying their stakeholders (Bertrand and Busugutsala 1998). Jongbloed et al. (2008) state that the university's ability to identify, prioritise and engage with communities mirrors the degree of organisational evolution.

From a theoretical perspective, the identification and salience of stakeholders involves three concepts, which can be used to characterise stakeholders (Parent and Deephouse 2007). These three concepts are power, legitimacy and urgency, which Carroll and Buchholtz (2014) describe as a typology of stakeholder attributes. Power refers to stakeholders' ability to arbitrarily and coercively exercise their will over a relationship (Carroll and Buchholtz 2014; Parent and Deephouse 2007), and stakeholders' power ultimately influences the organisation (Jongbloed et al. 2008). The legitimate interest of stakeholders in an organisation is what defines them (Pesqueux and Damak-Ayadi 2005), and a legitimate stakeholder's action and claims are understood as being appropriate or legitimate, as well as proper and desirable (Carroll and Buchholtz 2014; Jongbloed et al. 2008; Parent and Deephouse 2007). Urgency refers to the extent to which stakeholders view their claims as being critical and time-sensitive (Carroll and Buchholtz 2014; Mitchell et al. 2007; Parent and Deephouse 2007). The degree to which a stakeholder is salient depends on how many of these attributes he or she has (Parent and Deephouse 2007), which in turn determines how great his or her influence on university decision-making processes will be (Mitchell et al. 1997).

Table 1: Stakeholder types

\begin{tabular}{|l|c|l|l|}
\hline & Class & Stakeholder type & Attributes \\
\hline \multirow{2}{*}{$\begin{array}{l}\text { Latent stakeholders (classes: 1,2,3) } \\
\text { possess only one attribute }\end{array}$} & 1 & Dormant & Power \\
\cline { 2 - 4 } & 2 & Discretionary & Legitimacy \\
\cline { 2 - 4 } & 3 & Demanding & Urgency \\
\hline \multirow{2}{*}{$\begin{array}{l}\text { Expectant stakeholders (classes: 4,5,6) } \\
\text { possess two attributes }\end{array}$} & 4 & Dominant & Power and legitimacy \\
\cline { 2 - 4 } & 5 & Dangerous & Power and urgency \\
\cline { 2 - 4 } & 6 & Dependent & Legitimacy and urgency \\
\hline $\begin{array}{l}\text { Definitive stakeholders (Class:7) } \\
\text { possess all three attributes }\end{array}$ & 7 & Definitive & Power, legitimacy and urgency \\
\hline
\end{tabular}

Source: Adopted from Jongbloed et al. $(2008,310)$ 
According to Bobeica (2011), dormant stakeholders have sufficient power to impose their will on an organisation. Nevertheless, because they lack a legitimate relationship or urgent claim, this power cannot be exerted. Discretionary stakeholders have legitimacy, but lack the power to influence the organisation, and do not have urgent claims. On the other hand, demanding stakeholders only have the attribute of urgency, hence they are viewed as “demanding”.

If stakeholders are both powerful and legitimate, their influence is ensured, since their power and legitimacy enables them to form the "dominant coalition" in the organisation. Dependent stakeholders do not possess power, but do have urgent and legitimate claims, which means that they depend upon others (for the power to do their will). Mitchell et al. (1997) indicate that dangerous stakeholders are those who possess the attributes of urgency and power, but lack legitimacy. Consequently, such a stakeholder will be coercive and potentially violent, which makes him or her "dangerous" to the organisation. However, definitive stakeholders possess all three attributes, namely power, legitimacy and urgency.

Stakeholder types differ according to the degree of salience that they have (Mitchell et al. 1997). The three attributes are dynamic, not static (Carroll and Buchholtz 2014; Benneworth and Jongbloed 2010). The evolving social contract between universities and society may lead to what could be described as a "non-stakeholder" becoming a legitimate stakeholder or more (Benneworth en Jongbloed 2010). Transformation within society and changes in ways of thinking therefore give managers new responsibilities (Jackson 2003).

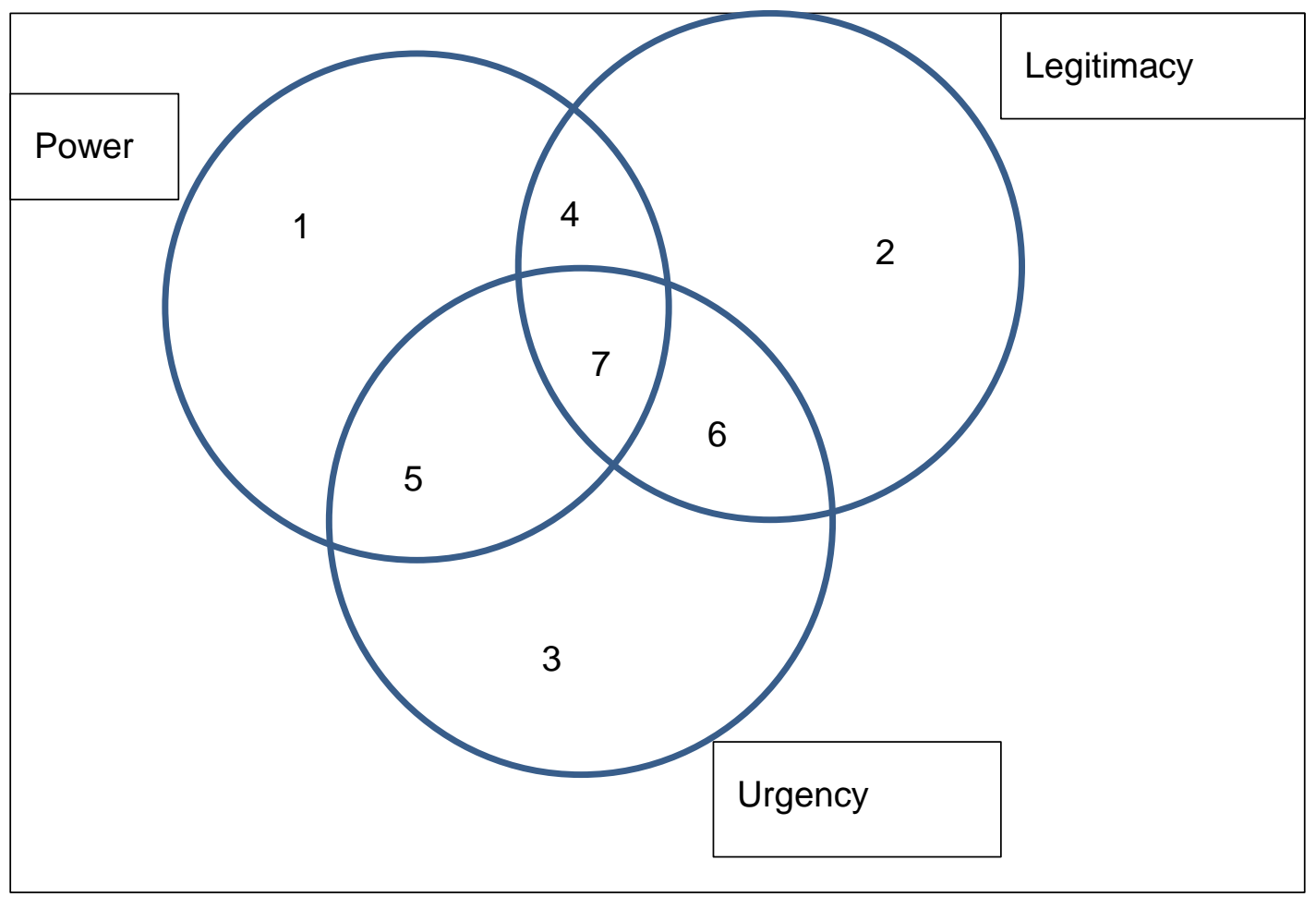

Figure 1: A stakeholder typology (Source: Jongbloed et al. 2008, 310) 
The types of stakeholder theories include normative, instrumental and descriptive theories (Berman et al. 1999; Carroll and Buchholtz 2014). The normative value or realm focuses on how to deal with corporate stakeholders and moral commitment (Carroll and Buchholtz 2014; Berman et al. 1999). It is about the fundamental principles that guide the organisation in terms of conducting its business (Berman et al. 1999). The normative model is predicated on two different, though related, sources of business ethics literature: the development of the model is based on the idea that the organisation's decisions have an impact on stakeholder outcomes, and the second genesis of the normative stakeholder model is based on the strategic application of ethical principles: if organisations adhere to moral principles only when this is to the organisation's advantage, it is not viewed as acting in accordance with ethical principles (Berman et al. 1999).

In the instrumental realm, stakeholders are viewed as part of the environment that needs to be managed for survival (Berman et al. 1999). According to Freeman (in Berman et al. 1999, 491), "we need to worry about enterprise level strategy for the simple fact that corporate survival depends in part on there being 'fit' between the values of the corporation and its managers”. This encapsulates the original argument for instrumental value. To gain instrumental benefits, an organisation needs to demonstrate a commitment to maintaining ethical and moral stakeholder relationships, irrespective of the benefits that are expected (Berman et al. 1999). The descriptive model concentrates on how to manage stakeholders (Berman et al. 1999).

\section{A UNIVERSITY AS A COMPLEX ADAPTIVE SYSTEM}

The university is a system that comprises various sub-systems, and its stakeholders represent different systems (Freeman 2015). A university is a complex adaptive system that needs strong stakeholder management strategies to continually adapt to the university's needs and expectations, as well as those of its stakeholders. According to Jackson (2003), a system is a complex whole, and its functions rely on its parts, as well as the interactions between these parts. As a system, the university is embedded in national and regional systems (Jongbloed et al. 2008). Like any other business, a university operates in complex, ever-changing, diverse and shifting environments. A complex organisation is a set of interdependent parts that combine to make up a whole, which also functions interdependently with larger environments (Anderson 1999).

As observed by Neave (quoted in Jongbloed et al. 2008, 305), the term "university” originates from the legal Latin word "universitas", meaning "community", and from the 
classical Latin word “universus”, which means “totality”. Boulton and Lucas $(2011,2506)$ state that "it is the totality of the university enterprise that is important, as the only place where that totality of ourselves and our world is brought together, and which makes it the strongest provider of the rational explanation and meaning that societies need”. In open systems, inputs are received from their environments, which are then transformed and returned to the environments as products (Anderson 1999; Jackson 2003). Since they comprise interconnected parts that work together, they are classified as systems (Anderson 1999). The reductionist approach that universities employ cannot assist in understanding what stakes do stakeholders claim.

Jongbloed et al. (2008) emphasise the importance of viewing the university as a complex social actor. A complex system seems to exhibit “disorder, irregularities and unpredictability”, and cannot therefore be understood from a scientific perspective (Anderson 1999; Jackson 2003). Scientific understanding refers to reductionism (Jackson 2003). A complex system requires both self-organisation and emergence, and is changing the worldview from one of being non-linear, dynamic and unpredictable, to one that is understandable, real and virtual (Agar 2007). Because today's university governance and the environment in which it functions are characterised by complexity, it is not easy to understand all the dimensions of decisions to be taken, nor can one predict the effects thereof (Emmeche 2015). Jackson (2003, xi) states that the "complexity stems from the nature of the problem". The management of stakeholders entails a symbiotic and epistemological relationship between system-in-focus, stakeholders and the environment, and requires a multi-disciplinary approach. Stakeholder theory is a multidisciplinary field that relates to four social sciences, namely economics, sociology, politics, and ethics, and draws from systems theory, corporate planning, social responsibility, and organisational studies (Mainardes et al. 2012).

With regard to non-linear systems, changing one or two parameters can lead to the behaviour of the whole system being changed (Anderson 1999). Knowledge production is interand trans-disciplinary, non-linear, application-driven and transient, which also expands on the number of research or knowledge actors (Ntshoe 2004). Therefore, complex systems transform inputs into outputs, which occurs in a non-linear fashion (Anderson 1999).

As complex organisations, universities have struggled to determine a methodology that can be implemented to measure the achievement of sustainability objectives (Vagnoni and Cavicchi 2015). Universities must employ creative holism in their quest for successful stakeholder management, in order to survive. Systems' thinking posits that leaders should adopt a systemic approach, which will enable them to examine problem areas and determine how to resolve them from a variety of perspectives (Jackson 2003). 


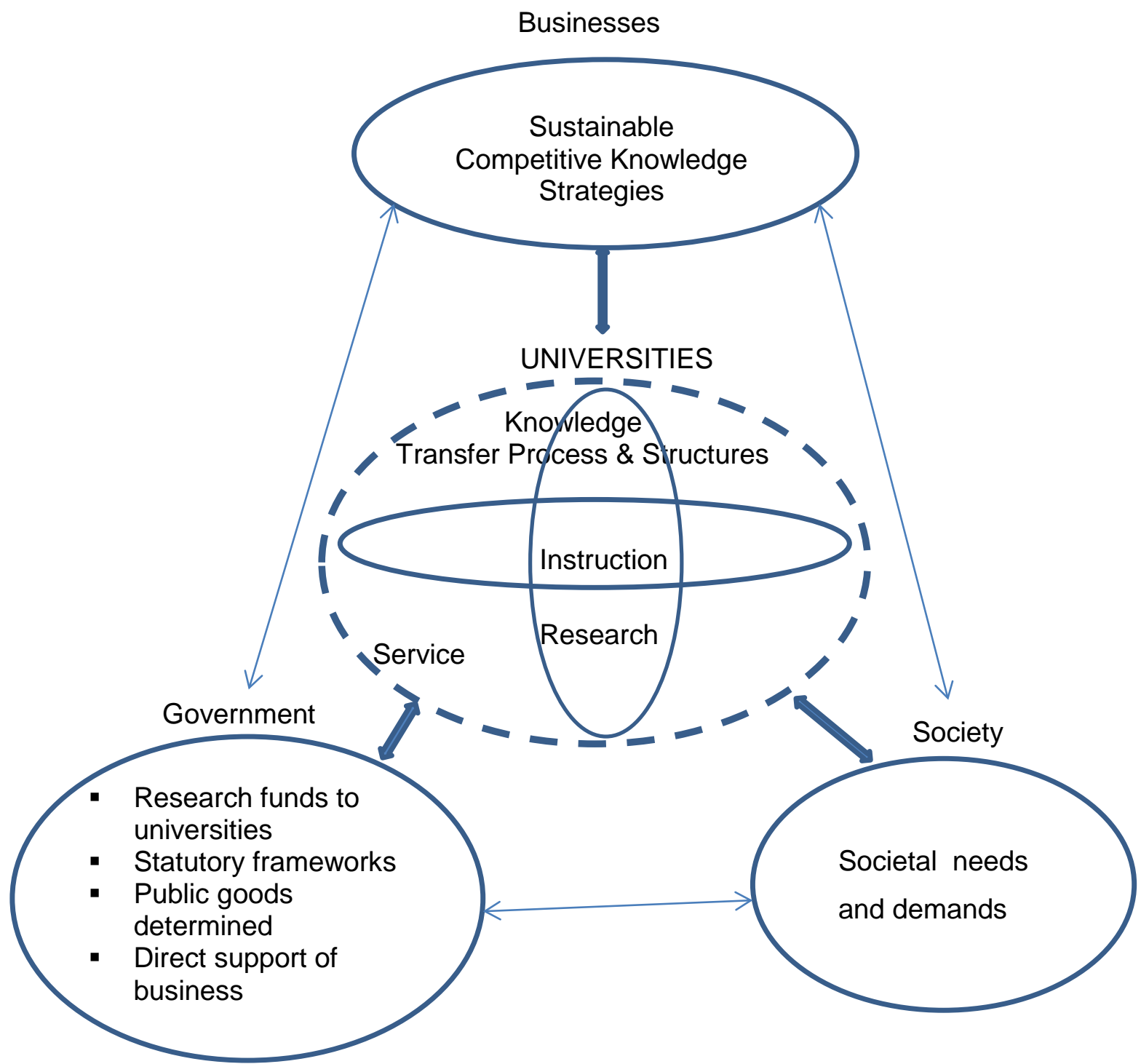

Figure 2: Knowledge transfer processes and the interdependencies between businesses, government, society and universities (Source: Stevens and Bagby 2001, 261)

Processes are used in stakeholder management to identify, manage and control people, groups or organisations that can influence or be influenced by the project (Purvis, Zagenczyk and McCray 2015). Jackson (2003) argues that today’s problems are more complex, and that solutions to these problems should therefore come from various disciplines.

\section{THE RESPONSIBILITY OF THE UNIVERSITY TOWARDS ITS STAKEHOLDERS}

According to Green (2014), as an institution, a university has a distinct identity, and plays a significant role in society. The university has been founded on discipline-based knowledge, as well as its development and dissemination (Laurillard 2000). Furthermore, the university’s reputation is still determined by internal scholarly achievements and disciplinary values (Jongbloed et al. 2008). 
According to Hackett (2014), there is a need for a research and education system that will contribute to knowledge development, poverty alleviation, and well-being of society. As stated by Bawa (2012, 669), universities "are social entities that help societies shape the way in which they think about themselves and how they relate with the rest of society and how societies relate to other societies”. Universities have changed from "communities of scholars" to "workplaces” (Teelken 2012, 272). The demands for interaction with stakeholders emanate from within the university and partly from outside the scientific community (Jongbloed et al. 2008). Essentially, universities must account to government and society at large for their activities (Jongbloed 2010). The prosperity of modern nations ultimately depends on the productivity of their citizens (Laurillard 2000).

Renault (2006) states that universities contribute to regional economic development in various ways. According to Jongbloed et al. (2008), universities should not only be known for their excellent education and ground-breaking research, but also need to shape the knowledge society. Inevitably, change is the product of this era (Jackson 2003). The change in the mission and role of universities has an impact on their relationships with their communities (Jongbloed et al. 2008).

A third mission of universities has been introduced because of the increased role of knowledge and research in economic development. This change has encouraged a re-evaluation of the university's mission and role in society (Etzkowitz and Leydesdorff 2000). Ramli et al. (2013) argue that the university's role in producing new knowledge is now being performed by privately funded research institutions. Activities associated with the third mission include everything besides traditional research and teaching (Jongbloed et al. 2008).

Due to this focus on the third mission, universities have counted society, public organisations and enterprises as some of their main stakeholders (Vagnoni and Cavicchi 2015).

As universities become academic enterprises that are dependent on capital allocations, it impacts on their power to act as an independent moral force (Hackett 2014) and become more integrated into society (Jongbloed et al. 2008). The university has a responsibility to develop citizens, transmit values, and to defend and promote the national culture (Amaral and Magalhaes 2002). Universities are increasingly under tremendous political pressure to be governed in terms of a "narrow set of measures of output efficiency and job creation effects", at the expense of their core business of tertiary education and research (Emmeche 2015).

The establishment of a community engagement agenda provides universities with various opportunities to operate as "sites of citizenship” (Jongbloed et al. 2008). Since universities have assumed the third mission, they have the responsibility to directly contribute to society and economic development (Martinelli, Meyer and Von Tunzelmann 2008). Their contribution to 
their community's social and economic infrastructure includes, among other things, development of social capital, helping to resolve local issues, education for democratic citizenship, and supporting equity and diversity (Jongbloed et al. 2008).

When dealing with the university as a complex system, the application of models of complex adaptive systems to strategic management results in an emphasis on building systems that can effectively provide adaptive solutions (Anderson 1999). Complex adaptive models are an important link to change and future outcomes (Cheng et al. 2006). In a world of complexity and change, high levels of diversity need to be managed (Jackson 2003).

According to Etzkowitz and Leydesdorff (2000), universities should return to their traditional role, which is teaching and research, and these authors question whether or not universities should add a third mission, namely that of economic development. As university stakeholders increase in number, so have society's expectations regarding the university's public responsibilities (Jongbloed et al. 2008). The factors that hinder the university's achievement of its core business are, among others, "authoritarianism, corporatism, illiberalism, supernaturalism, and political correctness” (Bowen, Schwartz and Camp 2013).

\section{UNIVERSITY STAKEHOLDER MANAGEMENT}

The future of universities includes the recognition of the demands of multiple actors that are linked in some way to higher education (Hagenbuch 2006). Recently, universities have been functioning as closed entities, isolated from their external environment, but are now expected to interact with many different stakeholder groups (Anderson, Briggs and Burton 2001). Since the tertiary education environment and tertiary education systems are constantly changing, universities can no longer afford to operate as "separated closed" institutions that fail to respond to their environment and stakeholders (Slabá 2015).

Higher education entails multiple stakeholders that simultaneously complement and contradict each other (Conway, Mackay and Yorke 1994). Institutions of higher learning have begun to acknowledge the importance of meeting the various needs of their stakeholders (Mainardes et al. 2012). However, Macfarlane and Lomas (1999) argue that these different interests create conflict, which management encounters when dealing with competing demands and expectations. The tertiary education market is challenged by the following factors: increasing competition, declining enrolments, globalisation, changes in tertiary education systems, a demographic curve in developed countries, global comparisons of universities, consequences of economic and financial crises, which impact university funding, and a decrease in public expenditure on educational institutions (Green 2014; Anderson et al. 2001; Lumby and Foskett 1999; Park 2011). 
Preston and Donaldson (1999) posit that stakeholder management can enhance an organisation's wealth, and that positive relationships between an organisation and its stakeholders can reap positive benefits. According to Clement (2005), contemporary organisations are under increasing pressure to respond to identified stakeholder groups.

Stakeholder governance presents an opportunity to enhance the participation of internal and external stakeholders in decision-making, and includes nominations beyond the group of stakeholder representatives (Taylor 2013; Alfred 1985; Gilmour Jr. 1991). The university has the capacity to thrive in turbulent environments, by meeting stakeholders' needs and resolving its internal problems, which enables it to determine the institution's stakeholder orientation (Clarke, Flaherty and Mottner 2001; Tam 2005).

\section{CONCLUSION}

For a long period, universities have been pandering to the notion that they can operate as a “closed system”. Universities, like any other business, are dependent on stakeholders for their survival. They have to conduct a stakeholder analysis to understand the attributes of their stakeholders, and must also identify their stakeholders. The nomenclature in universities should change to include an understanding of the term "stakeholder" in its full sense. Nowadays, the term "stakeholder" is used interchangeably with "publics".

A university is a complex adaptive system that operates in complex environments. The days of a reductionist approach to stakeholder management are over, and creative holism is the way forward for universities, in order to employ a multi-disciplinary approach to the challenges they encounter with regard to stakeholder management. A university, as a system-in-focus, must traverse to the higher level of fitness landscape. To achieve this, it has to consider stakeholder management as essential to its survival. To enable universities to respond to stakeholders' competing needs, "strong management” in the educational realm is needed, with a fundamental paradigm shift towards "economic rationalism” in educational service provision. The university space is not only a place of learning anymore, but has become an appendage of capital with a profit marginalisation agenda, which inevitably leads to the exclusion of others.

\section{REFERENCES}

Agar, M. 2007. Rolling complex rocks up social service hills: A personal commentary. EmergenceMahwah-Lawrence Erlbaum 9(3): 97-106

Agle, B. R. 2008. Dialogue: Toward superior stakeholder theory. Business Ethics Quarterly 18(2): 153190.

Alfred, R. L. 1985. Organizing for renewal through participative governance. New Directions for Higher Education 49: 57-63. 
Amaral, A. and A. Magalhaes. 2002. The emergent role of external stakeholders in European higher education governance. In Governing higher education: National perspectives on institutional governance: 1-21. Netherlands: Springer.

Anderson, L., A. R. J. Briggs and N. Burton. 2001. Managing Finance, Resources and Stakeholders in Education. London: Paul Chapman.

Anderson, P. 1999. Perspective: Complexity theory and organization science. Organization science 10(3): 216-232.

Bawa, A. C. 2012. South African higher education: At the center of a cauldron of national imaginations. Social Research: An International Quarterly 79(3): 669-694.

Benneworth, P. and B. W. Jongbloed. 2010. Who matters to universities? A stakeholder perspective on humanities, arts and social sciences valorisation. Higher Education 59(5): 567-588.

Berman, S. L., A. C. Wicks, S. Kotha and T. M. Jones. 1999. Does stakeholder orientation matter? The relationship between stakeholder management models and firm financial performance. Academy of Management Journal 42(5): 488-506.

Bertrand, D. and G. G. Busugutsala. 1998. Organisation of first-cycle teaching at university: Models and issues. Higher Education Management 10: 109-136.

Bobeica, A. M. 2011. Stakeholder's role in healthcare services and new information technology. Journal of Information Systems \& Operations Management 5(21): 551-560.

Boulton, G. and C. Lucas. 2011. What are universities for? Chinese Science Bulletin 56(23): 2506-2517.

Bowen, W. M., M. Schwartz and L. Camp. 2013. The end of academic freedom: The coming obliteration of the core purpose of the university. Information Age Publishing.

Burrows, J. 1999. Going beyond labels: A framework for profiling institutional stakeholders. Contemporary Education 70(4): 5.

Carroll, A. and A. Buchholtz. 2014. Business and society: Ethics, sustainability, and stakeholder management. Cengage Learning.

Cheng, P., C. C. Millar and C. Ju Choi. 2006. Organizational change in stakeholder business systems: The role of institutions. Journal of Organizational Change Management 19(3): 383-392.

Clarke, I., T. B. Flaherty and S. Mottner. 2001. Student perceptions of educational technology tools. Journal of Marketing Education 23(3): 169-177.

Clarkson, M. 1994. A risk based model of stakeholder theory. Proceedings of the Second Toronto Conference on Stakeholder Theory. Centre for Corporate Social Performance and Ethics, University of Toronto.

Clarkson, M. 1995. A stakeholder framework for analyzing and evaluating corporate social performance. Academy of Management Review 20(1): 92-117.

Clement, R. W. 2005. The lessons from stakeholder theory for US business leaders. Business Horizons 48(3): 255-264.

Conway, T., S. Mackay and D. Yorke. 1994. Strategic Planning in Higher Education: Who are the Customers? International Journal of Educational Management 8(6): 29-36.

Doh, J. P. and N. R. Quigley. 2014. Responsible leadership and stakeholder management: Influence pathways and organizational outcomes. The Academy of Management Perspectives 28(3): 255274.

Ehlers, T. and K. Lazenby. 2007. Strategic management. South Africa concept and cases. 2nd edition. Pretoria: Van Schaik.

Emmeche, C. 2015. The borderology of friendship in academia. AMITY: The Journal of Friendship Studies 3(1): 40-59.

Etzkowitz, H. and L. Leydesdorff. 2000. The dynamics of innovation: From National Systems and "Mode 2" to a Triple Helix of university-industry-government relations. Research policy 29(2): 109-123. 
Felix, O. and J. O. Ogbor. 2014. The quest for sustainable development: Strategies for managing stakeholder relationships. European Journal of Business and Management 6(35): 179-186.

Freeman, R. E. 2015. Stakeholder theory. Wiley Encyclopedia of Management, Vol. 2. John Wiley and Sons, Ltd.

Freeman, R. E. 1994. The politics of stakeholder theory: Some future directions. Business Ethics Quarterly 4(4): 409-421.

Freeman, R. E. and J. McVea. 2001. A stakeholder approach to strategic management. In The Blackwell handbook of strategic management, ed. M. A. Hitt, R. E. Freeman, J. S. and Harrison, 189-207. Oxford: Blackwell.

Freeman, R. E., A. C. Wicks and B. Pamar. 2004. Stakeholder theory and the corporate objective revisited. Organization Science 15(3): 364-369.

Gilmour, Jr., J. 1991. Your Faculty Senate: More effective than you think? Academe 77(5): 16-18.

Green, P. 2014. Service system interactions at tertiary institutions: A South African perspective. The International Business \& Economics Research Journal (Online) 13(1): 11.

Hackett, E. J. 2014. Academic capitalism. Science, Technology, \& Human Values 39(5): 635-638.

Hagenbuch, D. J. 2006. Service learning inputs and outcomes in a personal selling course. Journal of Marketing Education 28(1): 26-34.

Hakansson, H. and D. Ford. 2002. How should companies interact in business networks? Journal of Business Research 55(2): 133-139.

Jackson, M. C. 2003. Systems thinking: Creative holism for managers. Chichester: Wiley.

Jones, R. 2002. Challenges to the notion of publics in public relations: Implications of the risk society for the discipline. Public Relations Review 28(1): .49-62.

Johansson, C. 2009. On Goffman: Researching relations with Erving Goffman as Pathnder. In Public Relations and Social Theory, 127-148, Routledge.

Jongbloed, B. 2010. Funding higher education: a view across Europe. Bruxelles: European Centre for Strategic Management of Universities.

Jongbloed, B., J. Enders and C. Salemo. 2008. Higher education and its communities: Interconnections, interdependencies and a research agenda. Higher Education 56(3): 303-324.

Laurillard, D. 2000. New technologies and the curriculum. In Higher education re-formed, ed. P. Scott, 133-153. London: Falmer Press.

Louw, L. and P. Venter. 2008. Strategic management. Cape Town: Oxford University Press Southern Africa.

Lumby, J. and N. Foskett. 1999. Managing external relations in schools and colleges: International dimensions. Sage.

Macfarlane, B. and L. Lomas. 1999. Stakeholder conceptions of quality in single company management education. Quality Assurance in Education 7(2): 77-84.

Mainardes, E. W., H. Alves and M. Raposo. 2010. An exploratory research on the stakeholders of a university. Journal of Management and Strategy 1(1): 76.

Mainardes, E. W., H. Alves and M. Raposo. 2012. A model for stakeholder classification and stakeholder relationships. Management Decision 50(10): 1861-1879.

Mainardes, E.W., M. Raposo and H. Alves. 2012. Public university students' expectations: An empirical study based on the stakeholder theory. Transylvanian Review of Administrative Sciences 8(35): 173-196.

Martinelli, A., M. Meyer and N. Von Tunzelmann. 2008. Becoming an entrepreneurial university? A case study of knowledge exchange relationships and faculty attitudes in a medium-sized, researchoriented university. The Journal of Technology Transfer 33(3): 259-283.

Mitchell, R. K., B. R. Agle and D. J. Wood. 1997. Toward a theory of stakeholder identification and 
salience: Defining the principle of who and what really counts. Academy of Management Review 22(4): 853-886.

Mitchell, R. K., L. W. Busenitz, B. Bird, C. Marie-Gaglio, J. S. McMullen, E. A. Morse and J. B. Smith. 2007. The central question in entrepreneurial cognition research. Entrepreneurship Theory and Practice 31(1): 1-27.

Mok, K. H. 1999. Education and the market place in Hong Kong and Mainland China. Higher Education 37(2): 133-158.

Ntshoe, I. M. 2004. Higher education and training policy and practice in South Africa: Impacts of global privatisation, quasi-marketisation and new managerialism. International Journal of Educational Development 24(2): 137-154.

Parent, M. M. and D. L. Deephouse. 2007. A case study of stakeholder identification and prioritization by managers. Journal of Business Ethics 75(1): 1-23.

Park, T. 2011. Academic capitalism and its impact on the American professoriate. Journal of the Professoriate 6(1): 84-96.

Payne, A., D. Ballantyne and M. Christopher. 2005. A stakeholder approach to relationship marketing strategy: The development and use of the "six markets" model. European Journal of Marketing 39(7/8): 855-871.

Pearce, J. A. and R. B. Robinson. 2007. Strategic management: Strategy formulation and implementation. Richard D. Irwin Inc.

Pesqueux, Y. and S. Damak-Ayadi. 2005. Stakeholder theory in perspective. Corporate Governance: The International Journal of Business in Society 5(2): 5-21.

Polonsky, M. 1995. A stakeholder theory approach to designing environmental marketing strategy. The Journal of Business \& Industrial Marketing 10(3): 29-37.

Polonsky, M. J., L. Carlson and M. Fry. 2003. The harm chain: A public policy development and stakeholder perspective. Marketing Theory 3(3): 345-364.

Preston, L. and T. Donaldson. 1999. Stakeholder management and organizational wealth. Academy of Management Review 24(4): 619-620.

Prokopy, L. S., J. S. Carlton, J. G. Arbuckle Jr., T. Haigh, M. C. Lemos, A. S. Mase, N. Babin, M. Dunn, J. Andresen, J. Angel and C. Hart. 2015. Extension's role in disseminating information about climate change to agricultural stakeholders in the United States. Climatic Change 130(2): 261272.

Purvis, R. L., T. J. Zagenczyk and G. E. Mccray. 2015. What's in it for me? Using expectancy theory and climate to explain stakeholder participation, its direction and intensity. International Journal of Project Management 33(1): 3-14.

Ramli, N., Z. A. Zainol, J. A. Aziz, H. M. Ali, J. Hassim, W. M. H. W. Hussein, R. Markom, W. S. A. W. Dahalan and N. I. Yaakob. 2013. The concept of research university: The implementation in the context of Malaysian University System. Asian Social Science 9(5): 307.

Renault, C. S. 2006. Academic capitalism and university incentives for faculty entrepreneurship. The Journal of Technology Transfer 31(2): 227-239.

Slabá, M. 2015. Stakeholder groups of public and private universities in the Czech Republic Identification, categorization and prioritization. Review of Economic Perspectives 15(3): 305326.

Stevens, J. M. and J. W. Bagby. 2001. Knowledge transfer from universities to business: Returns for all stakeholders. Organization 8(2): 259-268.

Sturmberg, J. P., C. M. Martin and D. A. Katerndahl. 2014. Systems and complexity thinking in the general practice literature: An integrative, historical narrative review. Annals of Family Medicine 12(1): 66-74.

Tam, F. W. M. 2005. School-community relations: Reality and tensions. (Article written in Chinese). Journal of Basic Education 14(2): 1-20. 
Taylor, M. 2013. Shared governance in the modern university. Higher Education Quarterly 67(1): 8094.

Teelken, C. 2012. Compliance or pragmatism: How do academics deal with managerialism in higher education? A comparative study in three countries. Studies in Higher Education 37(3): 271-290.

Tetřevová, L. and V. Sabolová. 2010. University stakeholder management. In Conference proceedings of 7th WSEAS International Conference Engineering Education Vol. 10: 141-145.

Vagnoni, E. and C. Cavicchi. 2015. An exploratory study of sustainable development at Italian universities. International Journal of Sustainability in Higher Education 16(2): 217-236.

Wicks, A. C., D. R. Gilbert and R. E. Freeman. 1994. A feminist reinterpretation of the stakeholder concept. Business Ethics Quarterly 4(4): 475-497.

Zsolnai, L. 2006. Extended stakeholder theory. Society and Business Review 1(1): 37-44. 